\title{
PHYSOSTIGMINE AS AN ADJUVENT TO NEUROLEPTANAESTHESIA IN NEUROSURGICAL PROCEDURES
}

\author{
Dorothy E.A. Thompson
}

Neurosurgical operations which require the patient to co-operate with the surgeon may be done with local analgesia alone. However, this may be unpleasant for the patient and because of this and other factors such as the duration of the procedure, age, abnormal movement or severe pain, some form of sedation is often necessary. Various methods have been described. ${ }^{1-4}$

Operations requiring patient participation include stereotactic thalamotomies, percutaneous cordotomies, excision of cortical epileptiform foci and percutaneous coagulation of the Gasserian ganglion. They involve local excision of brain tissue or interruption of sensory or motor pathways by the production of a lesion in the brain or spinal cord. For a good surgical result, the site of the proposed lesion must be verified. For this the patient has to be alert enough to answer questions about sensory phenomena and to allow motor function to be tested. Ideal neurolepanaesthesia would provide these conditions while suppressing physical and mental discomfort. This ideal is not always achieved and often less than perfect sedation and analgesia are accepted to preserve reasonable alertness and co-operation. ${ }^{5}$

The anticholinesterase inhibitor physostigmine can be a useful aid in neuroleptanaesthesia. A patient may be deeply sedated and, when co-operation is required, can be awakened with intravenous physostigmine.

Physostigmine is a tertiary amine and, unlike neostigmine, it is unionised at body $\mathrm{pH}$ and so will cross the blood brain barrier. It reverses the central effects of a number of drugs including droperidol, ${ }^{6,7}$ diazepam, ${ }^{6,8,9}$ the phenothiazine derivatives and the belladonna alkaloids. ${ }^{10-12}$

The use of physostigmine is illustrated in the management of two children with dystonia musculorum deformans. Dystonia musculorum deformans is a progressive disense in which there are bizarre involuntary movements interfering with motor performance. There is no definitive pathology, and intellect is usually preserved. Control of the abnormal movement is sometimes achieved by electrocoagulation of part of the thalamus.

At Toronto General Hospital stereotactic thalamatomies are done in two stages. The first stage is done with a conventional general anaesthetic. It involves making a burr hole, screwing the stereotactic apparatus to the skull and making initial measurements of the thalamus with a ventriculogram. The second stage a few days later requires patient co-operation. The stereotactic frame is re-attached to the skull. The burr hole is re-opened and the site of the lesion is found and verified by electrostimulation of the thalamus.

The first patient was a boy 14 years of age weighing approximately $45 \mathrm{~kg}$. His

Dorothy E.A. Thompson, M.B., Ch.B., F.F.A.R.C.S., F.R.C.P.(C), Department of Anaesthesia, 'Toronto General Hospital, and the University of Toronto.

Canad. Anaesth. Soc. J., vol. 23, no. 6, November 1976 


\section{DROPERIDOL mg 2.5 \\ FENTANYL mg .05 \\ DIAZEPAM mg 7.5}

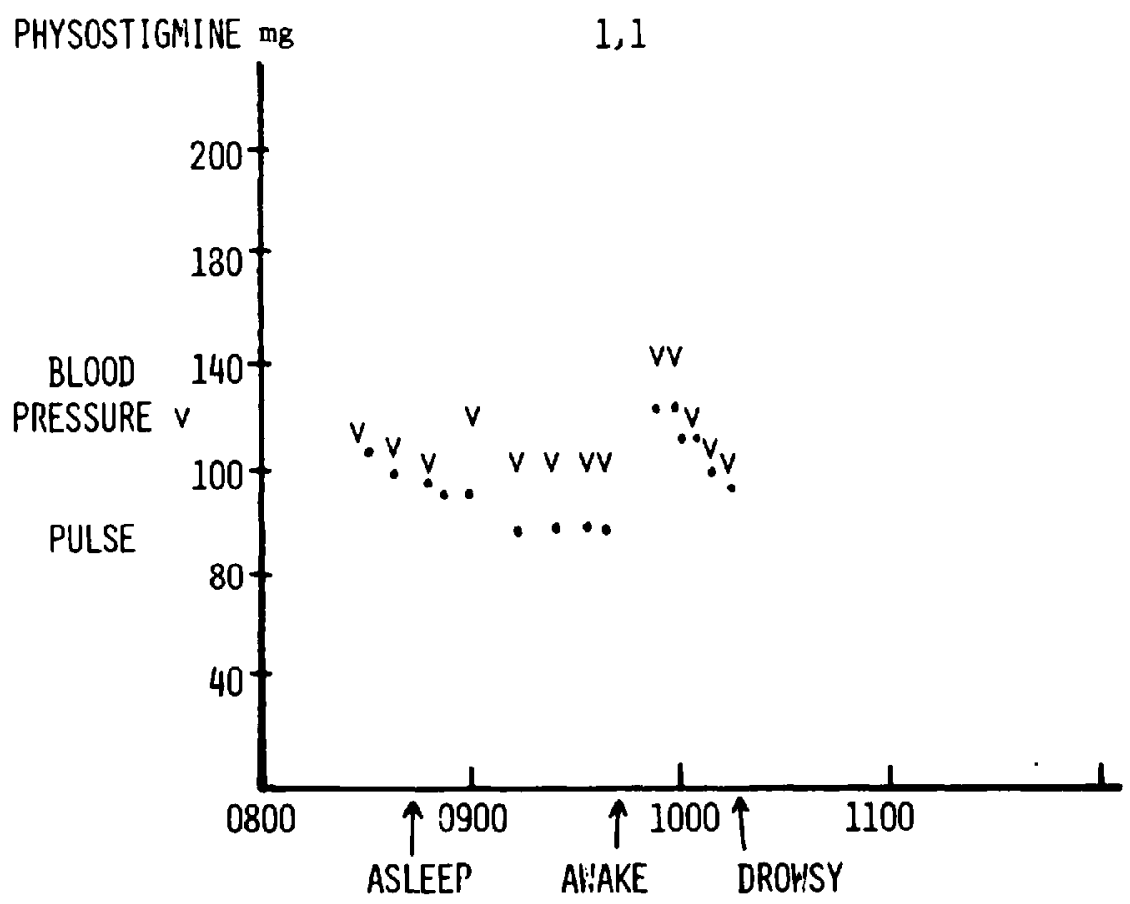

Figure 1.

dystonia was so severe that he could not lie in any position or sit because of continuous rotational movements of his trunk and arching of his neck. His laryngeal and pharyngeal muscles were also involved. Swallowing was difficult and he could no longer speak. His means of communication was by hand signals; he indicated yes, no and "O.K."

The anaesthetic for the first stage was uneventful. The second stage was repeated three times and management each time was similar. A combination of droperidol and diazepam was chosen, as this produces sleep with a small dose of each drug. A typical anaesthetic chart is shown in Figure 1.

Droperidol, diazepam and fentanyl were given intravenously in increments over a period of 10 to 15 minutes until he was asleep and unresponsive to pain. The dose of droperidol varied on the three occasions from $2.5 \mathrm{mg}$ to $3.75 \mathrm{mg}$ and of diazepam from $2 \mathrm{mg}$ to $7.5 \mathrm{mg}$.

The unpleasant part of the operation, before his co-operation was required, took from 40 to 75 minutes. His head was shaved, the stereotactic apparatus fixed to the skull, and the burr hole re-opened. He was asleep at this stage, but was awake within five minutes after a dose of physostigmine $2 \mathrm{mg}$ given intravenously. The 


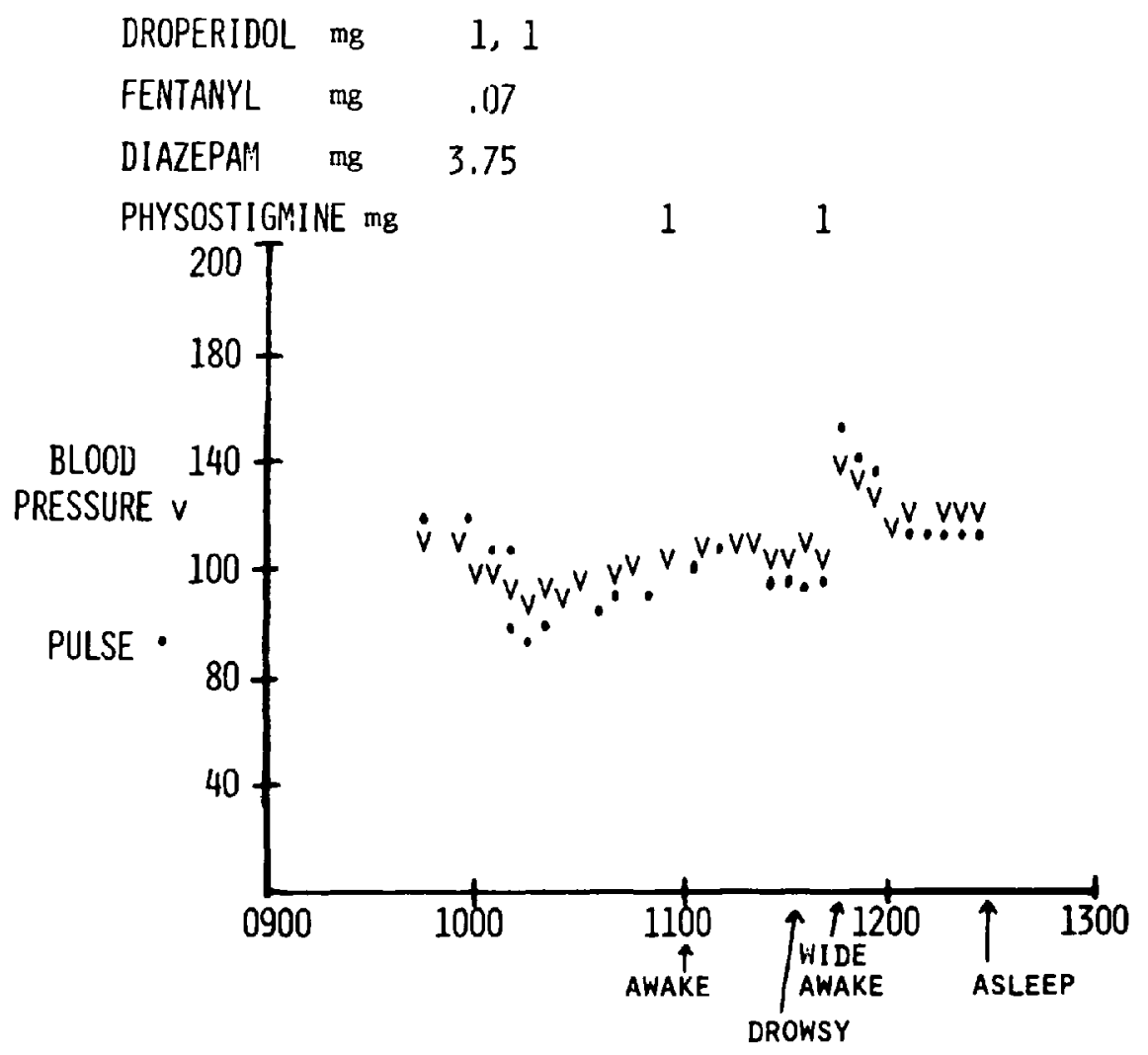

Ficure 2.

dystonia returned and he could localize sensation to his arm, shoulder or leg by answering direct questions with his hand signals. He became drowsy 30 minutes after the physostigmine and was asleep again after 40 minutes. He was accessible at all times during the operation and his chin could be supported when necessary. He remained drowsy until the next day and slept most of the time but could be roused.

The second patient was a girl eight years of age weighing $30 \mathrm{~kg}$. The dystonia affected one side only but prevented her from walking.

The anaesthetic for the first stage was uneventful except for severe post-operative vomiting. The second stage was repeated four times. Even though she was an intelligent co-operative girl it was thought unlikely that she could tolerate an operation lasting 3 to 4 hours without sedation.

A typical anaesthetic chart is shown in Figure 2. Sleep was induced on the four occasions with droperidal $2 \mathrm{mg}$ to $2.5 \mathrm{mg}$, diazepam $2.5 \mathrm{mg}$ to $5 \mathrm{mg}$ and fentanyl $0.05 \mathrm{mg}$ to $0.075 \mathrm{mg}$ given over a period of 10 to 15 minutes.

The unpleasant part of the procedure took from 35 to 60 minutes. She could then be roused by physostigmine $1 \mathrm{mg}$. She responded when spoken to two minutes after the physostigmine, could localize sensation and move on command. After 40 minutes she was too drowsy to co-operate but could be re-awakened with more physostigmine. On one occasion she became wide awake after the second dose of 
physostigmine, which was the same as the first. She was too aware of what was going on and became tearful. A smaller dose of physostigmine would have been better on this occasion. She vomited during one of these procedures, but the vomiting was not immediately related to the administration of physostigmine. She was awake and could be turned on her side without compromising the operation.

On the first occasion when this technique was used for each of these patients atropine and naloxone were given prior to physostigmine. This subsequently proved to be unnecessary.

\section{SUMMARY}

The use of physostigmine electively to reverse the effects of droperidal and diazepam has permitted an optimum level of neuroleptanaesthesia in neurosurgical operations where co-operation of the patient is required during part of the procedure. The patient can be put to sleep or readily awakened to be fully co-operative depending on the needs of the surgeon.

In this series of seven anaesthetics there were no side effects from the small doses of physostigmine employed. Bradycardia and salivation were not a problem. One child vomited once.

Atropine was not necessary. Since a narcotic antagonist is not needed, a reasonable degree of analgesia can be maintained in these patients while they are awake.

The latent time for the effect of physostigmine was two to four minutes and the effect of an intravenous dose lasted from 35 to 45 minutes. With physostigmine, these patients wake up gently as though from normal sleep.

If neurological assessment is required post-operatively, drowsiness due to drugs can be reversed by giving more physostigmine and the level of consciousness can then be assessed.

\section{RÉSUMÉ}

La physostigmine est un anticholinestérasique nonionisé qui traverse la barrière sang-cerveau et peut renverser certains effets de la neuroleptanesthésie. Elle a été utilisée au cours de procédures neurochirurgicales pour réveiller des patients et ainsi leur permettre de collaborer.

On rapporte ici le cas de deux enfants chez qui on a fait des thalamotomies stéréotactiques pour contrôler leur dystonie musculaire déformante. On devait les endormir pour une partie de l'intervention, vu leur jeune âge et les mouvements involontaires qu'ils présentaient. A cette fin, nous avons utilisé un mélange de dropéridol, de diazepam et de fentanyl. Les doses de dropéridol nécessaires pour ce ont varié entre $2 \mathrm{mg}$ et $3.75 \mathrm{mg}$, et celles de diazepam entre $2 \mathrm{mg}$ et $7.5 \mathrm{mg}$, doses données à doses croissantes sur une période de 10 à 15 minutes. Quand on a eu besoin de leur collaboration, les enfants ont pu être réveillés dans l'espace de deux à cinq minutes avec 1 à $2 \mathrm{mg}$ de physostigmine. Ce réveil était paisible, l’orientation bonne, et a duré 35 à 40 minutes. On pouvait répéter la physostigmine si nécessaire.

On n'a pas eu d'effets secondaires avec ces petites doses de physostigmine, non plus qu'on a eu besoin d'atropine. De plus, un certain niveau d'analgésie a pu être maintenu chez ces patients lorsqu'on les réveillait, vu qu'on n'avait pas à donner d'antagoniste des narcotiques. 


\section{REFERENCES}

1. Brown, A.S. Neuroleptanalgesia for the surgical treatment of Parkinsonism. Anaesthesia 19: 70-74 (1964).

2. Coleman, D.J. \& DeVillers, J.C. Anaesthesia and stereotactic surgery. Anaesthesia 19 : 60-69 (1964).

3. TAsker, R.R. \& Marshall, B.M. Analgesia for surgical procedures performed on conscious patients. Can. Anaes. Soc. J. 12: 29-33 (1965).

4. STEEN, S.N. Anesthetic management for basal ganglia surgery in patients with movement disorders. Anes. Anal. 44: 66-69 (1969).

5. Marshald, B.M. Neuroleptanaesthesia in neurosurgery. Int. Anesth. Clin. 11: No. 3, 103-124 (1973).

6. Rosenterg, H. Physostigmine reversal of sedative drugs. J.A.M.A. 229: 1168 (1974).

7. Bidwai, A.V., Connelius, L.R., \& STanley, T.H. Reversal of innover-induced postanesthetic somnolence and disorientation with physostigmine. Anesthesiology 44: 249-252 (1976).

8. Snyder, B.D., Blonde, L., \& McWhinter, R. Reversal of amitriptyline intoxication by physostigmine. J.A.M.A. 230: 1433-1434 (1974).

9. Bennards, W. Case history number 74 : reversal of phenothiazine-induced coma with physostigmine. Anesth. Analg. 52: 938-941.

10. Greene, L.T. Physostigmine treatment of anticholinergic drug depression in post-operative patients. Anesth. Analg. 50: 222-226 (1971).

11. Holzgraffe, R.E., Vondmell, J.A., \& Mintz, S.A. Reversal of post-operative reactions to scopolamine with physostigmine. Anesth. Analg. 52: 921-925 (1973).

12. Duvoisin, R.C. \& KATZ, R. Reversal of central anticholinergic syndrome in man by physostigmine. J.A.M.A. 206: 1963-1965 (1968). 